\title{
Putting in Check the Brazilian Moves in the Climate Chessboard
}

\author{
Thauan Santos* \\ Luan Santos**
}

\begin{abstract}
This paper discusses Brazil's role in climate governance, methodologically and metaphorically comparing it to chess pieces moves, based on national and regional official documents, commitments and data. Unlike other IR studies, our proposal suggests different behaviours at different levels of analysis for the same country. Nationally, the country played the role of pawn. Regionally, there is no unitary behaviour: in international cooperation (carbon pricing case), it moves like a queen; in the regional integration process (energy integration case), like a king. The current scenario raises doubts about these roles, suggesting that Brazil has been presenting an increasingly moderate and conservative behaviour in the past years.
\end{abstract}

Keywords: Brazil; climate change; 2030 Agenda; carbon pricing; international cooperation; energy integration; climate governance.

\section{Introduction}

The climate and sustainable development agenda has historically been of little relevance to issues related to hard power, such as military and defence, since they are relatively 'recent' topics in the area of international relations (IR). That way, and often being relegated to the background, this agenda is traditionally associated with soft power - either for being a tool not limited only to states, or for it encompasses ideological, social and cultural aspects.

However, it is possible to argue that these agendas have gained increasing relevance, especially from the different initiatives carried out from the 1970s. It is worth mentioning that Garrett Hardin's 'Tragedy of the Commons' (1968) was published in the late 1960s, with particular emphasis on the collective management of (common) natural resources and collective action failures. Hardin's work analyses a situation in which individuals, acting independently and rationally in accordance with their own interests, behave in opposition to the best interests of a certain community, hence exhausting some common

* Brazilian Naval War College (EGN), Rio de Janeiro-RJ, Brazil; thauan@marinha.mil.br. ORCID iD 00000002-4001-4322.

** Federal University of Rio de Janeiro (UFRJ), Rio de Janeiro-RJ, Brazil; luan.santos@pep.ufrj.br. ORCID iD 0000-0002-4131-1329. 
resource. The hypothesis hereby raised states that free access and the unrestricted demand for a finite resource ends up structurally condemning the resource due to its overexploitation, so it directly addresses the environmental and climate agendas. Notwithstanding, it was precisely with the turn of the $21^{\text {st }}$ century that such agendas gained weight and urgency on a global scale. As a result, the past 50 years have witnessed not only the evolution of the discussion of new environmental themes and different actors, but rather, above all, the emergence of new ways to face the challenges presented by different knowledge, disciplines and sciences.

Therefore, the main purpose of this paper is to discuss and evaluate the Brazilian climate governance considering the IR view, specifically understanding the consistency of the country's role, domestically and regionally. Without seeking to analyse the etymology of the term 'governance,' the paper is intended to contribute to the specialized literature from an analysis of the Global South, particularly focusing on the (regional) role of Brazil in terms of the $21^{\text {st }}$ century climate agenda. Ergo, we will not only address global governance, but also the country's role at the following levels: national, regional, and even global.

It is not the focus of this article to make a detailed analysis of the national climate policy or of all the initiatives that the country participates in, but instead, to analyse specific cases in order to assess the consistency of the Brazilian role. Although some actors and cases are cited throughout the text, the purpose of this article is not to map them. National perspectives are often offered by different states; on the other hand, global governmental commitments are widely disseminated and published by international organizations. The justification for this additional regional lens is due to the fact that the region accounts for a significant share of the world's tropical forests, potential arable land, freshwater reserves, important mineral reserves, and carbon emissions from land use (Baud et al 2011).

Similar to some studies on international politics, the analysis of Brazil's role will be methodologically and metaphorically compared to the chessboard/game (Kopper 2017; Marks 2011; Nye 2002; Putnam 1988), based on national and regional official documents, commitments and data. However, unlike the usual procedure, we will hereby evaluate how the movement of a chess piece changes depending on the level and context analysed. By playing with words, we say we 'put in check' its role as a regional player.

By 'movement of a chess piece,' we mean the net and aggregate result of different national interests that does not necessarily provide an exclusively state-centred perspective. In that sense, and considering the chessboard methodological restriction, national movements are unique, since they express more influential interests that change over time, with the political and economic situation.

Since climate change has been identified as one of the greatest economic and political challenges faced by the world economy (IPCC 2014), two regional cases that are embedded in the proposed analysis and that have often been ignored will be analysed from the point of view of Brazil's role. The first one evaluates Brazil's international cooperation through carbon pricing initiatives in Latin America. The second case focuses on energy integration within the scope of South America. 
We justify the joint treatment of the two cases, as both were advancing in the past decade, reinforcing the positive Brazilian self-image role in global climate governance (Franchini and Viola 2019) before recent changes took place. Besides, this directly relates with the argument of south-south environmental cooperation (Hochstetler and Inoue 2019) and with a Brazilian foreign policy more oriented to the Global South and sensitive to environmental and climate issues (Vieira 2012; Kiessling 2018). Therefore, starting from the view of international politics through environmental and climate governance, we use energy integration and carbon pricing as case studies to show how Brazil has been losing its role and relevance in this agenda, nationally, regionally and globally - fully in line with Mauad and Betsill (2019), Basso (2019), and Viola and Franchini (2018).

\section{Literature review: the climate chessboard}

International climate architecture can be compared to a chessboard, and specialized literature frequently places it within the 'environmental' scope, often analysing it from the point of view of governance. Despite the strong institutional influence that the term 'governance' adds to the concept, it calls upon globally agreed standards, international cooperation and regional integration, given the different initiatives that can and should be undertaken to address climate challenges.

Generally, the discussion on environmental governance is carried out from the perspective of global environmental governance (GEG). GEG comes from different economic, environmental, and social policies, as well as cultural values among different actors (not limited to states, but that takes into account subnational, regional and transnational actors), such as citizens, states, companies and NGOs (Saunier and Meganck 2009). Different Latin American authors analyse GEG from a regional perspective (Hochstetler and Inoue 2019; O'Ryan and Ibarra 2017; De Castro et al 2016; Hochstetler 2014), including different publications, as those by UN agencies for the Latin American and Caribbean region (Cepei 2018; Bárcena 2015).

Among its characteristics, it is possible to emphasize: (i) influence of the concept of national sovereignty, due to the 1648 Westphalia Settlement; (ii) influence of the international law and binding agreements, which often affects national law; (iii) relevance of some principles and other non-binding instruments; and (iv) the role of civil society in decision making. By presenting at least three not static core components: process, architecture and implementation (Saunier and Meganck 2009), GEG can be understood as a thematic island of the IR archipelago, although other subfields pay relatively little attention to it (Morin and Orsini 2013).

However, our main objective in this section is to question the benefit and efficiency of focusing on only one level of governance, suggesting the need to consider and give relevance to the regional perspective. The reason therefor is the fact that such perspective considers more appropriately the particularities of the countries involved, allowing for the exploitation of scale gains that are associated with international cooperation and regional integration. 
Since not all environmental issues will be taken into account, but specifically the climate one, Keohane and Victor (2011) stress that climate (change) differs from GEG, either by (i) forms of governance (multilateral, club, bilateral, expert); (ii) issues (adaptation, nuclear, trade, financial); and/or (iii) functions (scientific assessment, rule-making, financial assistance, capacity building). Held and Roger (2018) show how climate governance has changed between the Kyoto Protocol (1997), the Copenhagen Accord (2009) and the Paris Agreement (2015). These particularities become quite evident upon analysing Brazil's relevance in both regional carbon pricing and energy integration cases.

Given the limitations of tackling the problem of environmental/climate governance from a global perspective, several authors have begun to consider the possibility of doing so from a regional perspective because, in practice, some international environmental governance actually happens at the regional level. In fact, rather than dealing with excluding or opposing perspectives, they can work together to provide feedbacks to each other in order to better face the environmental and climate challenges.

In this vein, the regional environmental governance - known as REGov or REG (Balsiger 2011) not only takes into account the important principle of common but differentiated responsibilities (CBDR), but also avoids transaction costs, weaker compliance and lower common denominator approaches related to global perspectives (Debarbieux and Rudaz 2010). The CBDR principle has been widely used in environmental and climate discussions, including in Latin American countries (Franchini and Viola 2019; Silva 2015; Campello and Silveira 2012). Compared to global approaches, initiatives with a regional focus may benefit from enhanced 'commonalities' in a particular environmental challenge, greater familiarity with key actors, and from the ability to tailor mitigating action to a smaller than global constituency (Balsiger and VanDeveer 2010, 2012). Most specifically,

By virtue of its institutional definition, the regional level is conceived as a complement to other levels, notably the global and national levels. [...] Indeed, governance structures for the environment can be found on a multiplicity of levels (Balsiger and Debarbieux 2011: 3).

Therefore, it is possible to realize that, in reality, there is a multilevel governance (MLG) ranging from local to global level, through national and regional ones (Paavola 2016; Saito-Jensen 2015; Winter 2011).

Following the discussion on global, regional and multilevel environmental governance, the focus of this paper is on the role of Brazil's regionally. Recently, Latin American (LA) countries have played a key role in the debate on environmental challenges and climate change (World Bank et al 2019). Baud et al (2011) emphasize that from the mid1980s onwards, the environmental governance in LA witnessed different perspectives: (i) state-based centralized decisions; (ii) privatization-led and decentralization-led; and (iii) recently, higher participation of civil society and private enterprises. The edited book by Castro et al (2016), for example, discusses the post-neoliberal environmental governance in some LA regions, such as Bolivia and Ecuador, as well as local solutions for environmental justice. 
Regardless of the perspective, it is a fact that the regional view allows including sub-regions (e.g., the Amazon, Andes, Meso-America, the Caribbean) or more local contexts into consideration, as done by Faria and Magrini (2016), Viana et al (2016), Davenport et al (2017), Bizzo and Michener (2017) and Gebara et al (2019). However, the purpose of this paper is to look at areas barely discussed in the LA regional context. Unlike Becker (2001), who analyses the Amazonian frontiers at the beginning of the $21^{\text {st }}$ century, and in line with Viola and Franchini (2018), who investigate the Brazilian role in climate change beyond the Amazon, the next sections will evaluate both national paths and regional initiatives (carbon pricing and energy integration).

\section{National and global milestones}

Brazil has been an important player in the discussions about climate change and its policies in the last decades (Gurgel and Paltsev 2017; Viola and Franchini 2013). During the $15^{\text {th }}$ Conference of the Parties (COP 15), in Copenhagen in 2009, under the United Nations Framework Convention on Climate Change (UNFCCC) coordination, the country assumed a pioneering position among developing countries in terms of the commitments it made to mitigate climate change. Brazil announced volunteer goals to decrease emissions between $36.1 \%$ and $38.9 \%$ regarding emissions projected for 2020 . With the voluntary reduction proposal, the government intended to prevent the country from issuing between 975 million and 1 billion tonnes of carbon dioxide by 2020 (Brazil 2009), compared to forecasting emissions as if no action were taken (Business as Usual - BAU).

These (global) objectives agreed at COP 15 gained legal national force, following the enactment of Law 12.187/2009, which established the Brazilian National Policy on Climate Change (NPCC). The law aims to reduce anthropogenic GHG emissions and strengthen carbon removal through national sinks and foster measures that promote adaptation to climate change (Santos 2018). Overall, this objective is to be achieved through sectorial plans for adaptation and mitigation of climate change that take into account the specificities of each sector.

The Brazilian NPCC promoted the adoption of a voluntary national commitment to reduce projected GHG emissions by 2020 (World Bank 2011) regulated by Decree 7.390/2010, which establishes guidelines concerning legal articles and imposes emission targets for GHG by economic sectors (Brazil 2009, 2010). Moreover, Brazil is also implementing its NPCC through a broad range of integrated national policies and programs, including command-and-control measures, economic incentives, and public and private investments (Santos et al 2018). In addition to the expected engagement of the different actors (including the private sector), these policies and programs would require significant amounts of public resources by 2020 (CEBDS 2017; Brazil 2015a).

In its article 5, the NPCC affirms that the use of financial and economic instruments to promote mitigation and adaptation actions to climate change will be encouraged, and article 6 highlights that such mechanisms already exist in the scope of the UNFCCC, which must present environmental standards and measurable and verifiable targets (Brazil 
2009). Notwithstanding, changes in the emissions profile - in particular, from the NPCC's inspection of deforestation and illegal burning in the Amazon region - and potential new mitigation policies for the post-2020 period indicate the need to explore new economic instruments (Santos 2018). This is even more important considering the growth of fires and deforestation in the past years.

More recently, the COP 21 held in Paris in 2015 was a milestone in the history of international politics, achieved with the adoption of the Paris Agreement. Driven by longterm visions for development and sustainability, it aims to strengthen the global response to the challenges posed by climate change. To this end, it establishes the goal of limiting the increase in the average temperature of the planet to a level below $2^{\circ} \mathrm{C}$ in relation to pre-industrial levels, with an indication of efforts so that the limit of $1.5^{\circ} \mathrm{C}$ is not exceeded (Brazil 2015b).

As far as the presentation of the Brazilian Nationally Determined Contributions (NDC) at the international level, no sector commitments were reported, even though it is economy-wide, i.e., it covers all the economic sectors. The national territory was covered in the Brazilian NDC, and it was up to the government to define which sectors it intends to prioritize at the domestic level, as well as what policies and actions to implement. However, for internal purposes, in the process of quantifying the national contribution, the level of effort expected to be obtained from each sector for planning and considering the feasibility of the mitigation contribution was indicated (Brazil 2015a, 2015b).

In this context, Brazil has announced the target of reducing GHG emissions by $37 \%$ compared to 2005 levels by 2025 and the intention to reduce them by $43 \%$ by 2030 . Several indicative mitigation strategies were envisioned and explicitly described in the Brazilian NDC to be achieved by 2030 (Gurgel and Paltsev 2017; Ministry of Science, Technology and Innovation [Brazil] 2016). We stress eight of them: (i) achieve zero illegal deforestation; (ii) restoring and reforesting 12 million hectares (ha) of forests; (iii) increasing the share of sustainable biofuels in the energy mix to $18 \%$; (iv) achieving $45 \%$ of renewable energy sources in the energy mix; (v) increasing the share of renewables in the power supply to $23 \%$; (vi) achieving efficiency gains of $10 \%$ in the electricity sector; (vii) restoring 15 million ha of degraded pastures, and; (viii) expanding the area of integrated cropland-livestock-forestry systems by 5 million ha (Brazil 2015a, 2015b).

In short, Brazil has played a relevant role in the environmental and climate agendas in the last decades. Based on its domestic moves in the period analysed (2009-2015), one can verify Brazil's close relationship with the pawn, moving only one square forward. It is also the most numerous piece (given that it is only one country among many others on the international board) and initially less powerful (since it is only a single piece of that board, from the Global South). However, as a pawn in his first move, Brazil can advance one or two houses (a proxy for some audacious moves on the chessboard, like the boldness proposed at COP 15, for instance, the announcement of voluntary greenhouse gas mitigation targets).

Nonetheless, at the same time, the pawn cannot skip other pieces, having its path eventually blocked. This means that, on the other side, there may be limitations along 
the way that stem from national or regional obstacles. Nationally, the inability of some governments to halt the deforestation of the Amazon region has been a source of harsh criticism by international environmental activists (Vieira 2012). The National Institute for Space Research (INPE) recently announced that June 2020 presented the highest number of deforestation alerts in the entire historical series, which started in 2015. In the first half of the 2020, the alerts indicated devastation in $3,069.57 \mathrm{~km}^{2}$ of the Amazon, an increase of $25 \%$ compared to the first half of 2019. Only in June 2020, the alert area comprehended $1,034.4 \mathrm{~km}^{2}$ (INPE 2020).

Another historical practice that occurs in Brazil, responsible for recent and severe international criticism, as well as strong economic retaliation, is the burning of forests, in particular of the Amazon. This practice is very much used for cleaning and renovation of pastures for the livestock and agricultural sectors, directly related to land use. In 2019 alone, during the first year of the term of office of President Bolsonaro, there was an increase of over $40 \%$ in deforestation warnings between August and July. Between January and August of 2019, the fires increased by $83 \%$ when compared to the same period of 2018, according to the data released by INPE. The number is the highest in seven years, with nearly 73,000 fire points recorded, reaching the triple border between Brazil, Bolivia and Paraguay and consuming more than 20 thousand hectares of vegetation.

In addition to deforestation and burning, other agendas related to the environment and climate change are under serious threat in the current federal government, given their neglect and emptying in the political sphere. Among these, we can highlight the government's interest in extinguishing the legal reserve areas and revising the areas of conservation units; the weakening of the Ministry of Environment; the possibility of extinction of the Amazon Fund; the loosening of the forest code; the possibility of re-marking indigenous lands; and the increasing authorization for the use of new pesticides - only in the first 100 days of government, 152 were authorized, of which 44 were rated as highly or extremely toxic, representing a record compared to the last ten years (Greenpeace 2019). One cannot forget the government's refusal to host the $25^{\text {th }}$ Climate Conference (COP 25) in Brazil, arguing fiscal and budgetary constraints.

Given what has been happening domestically, we argue that Brazil has not been making the 'traditional' movement of the pawn just walking forward. Thus, it is understood that the country has been 'breaking the rule of the game', going backwards at the national level. However, in spite of the independent moves that a pawn can have, it can only protect the piece that is close to it. The pawns should advance together to form a solid pawn chain. Consequently, regardless of its interests and objectives, an isolated pawn could be an extremely fragile chess piece. Therefore, it is clear that the pawn move is stronger when it advances alongside with other pawns, demanding joint moves - which metaphorically leads us to evaluate the aforementioned need for greater international cooperation and regional integration. 


\section{Regional approach}

This section specifically assesses the role of Brazil regionally. After identifying the progressive advancement of the pawn at the national level (as well as its questionable moves, that suggest breaking the rules of the game), it is necessary to understand how the country acts in the regional scenario and, moreover, if there is a single behaviour at this level of analysis. To this end, we will evaluate two cases in which the country has a recognized regional role: (i) from the point of view of international cooperation, we will analyse the power of Brazil in the Latin American carbon pricing agenda; and (ii) from the point of view of regional integration, we will analyse the importance of Brazil in the energy integration of South America. Both cases were selected due to their great interface with the climate chessboard, particularly with regard to the emission mitigation agenda.

\section{Carbon pricing}

Carbon pricing gives flexibility to sector's efforts to reduce GHG emissions, allowing mitigation targets to be achieved more cost-effectively (Santos et al 2018). In addition, as a key component of an effective and efficient mix of climate policies, it also represents an important tool for risk management and the development of competitive advantages in a world in transition for decarbonization to the private sector (CEBDS 2016).

Policymakers have at their disposal command-and-control measures and market-based instruments. The later include the commercialization of GHG emissions permits (emissions trading schemes - ETS) and the taxation of emissions (carbon tax). Determining a price on carbon is fundamental to climate policy, so that different designs of carbon pricing instruments (CPI) are being developed by countries, taking into account national and regional specificities as well as the dynamics of involved sectors (ICAP 2018; World Bank 2016). According to the literature, the most economically-efficient way to reduce GHG emissions is through the use of CPI (CPLC 2017; Stavins 2008).

Currently, 46 national and 28 subnational (cities, states and subnational regions) jurisdictions are putting a price on carbon. Carbon pricing initiatives that are already in place and scheduled for implementation would cover approximately 11 gigatons of carbon dioxide equivalent $\left(\mathrm{GtCO}_{2} \mathrm{e}\right)$, roughly $20 \%$ of global emissions, compared to $8 \mathrm{GtCO}_{2}$, or about 15\% in 2017 (World Bank et al 2019).

In this context, and taking into account the Brazilian scenario, it is important to highlight that the Brazilian NDC also considers the use of economic mechanisms, but it is not clear about the configuration of the Brazilian climate policy in terms of economic instruments for carbon pricing (Santos 2018). Therefore, some issues become relevant when looking at the Brazilian NDC: how will the national climate policy be reshaped in terms of economic mechanisms and instruments for carbon pricing? What is the role of Brazil in the regional and global carbon pricing agendas?

As stated in the national NDC, 'Brazil reserves its position regarding the possibility of using any market mechanisms that may be established under the Paris Agreement' (Brazil 
2015b: 2). Furthermore, article 5 of the NPCC states that the use of financial and economic mechanisms that are national in scope and referring to mitigation and adaptation to climate change' will be encouraged, and article 6 emphasizes that such mechanisms are among those already existing within the framework of the UNFCCC, which must present environmental standards and quantifiable and verifiable targets (Brazil 2009).

In the same article, more specifically in item VI, there is a reference to the possibility of adopting a tax. According to the paragraph, 'fiscal and tax measures to encourage the reduction of emissions and removal of GHG, including differentiated rates, exemptions, compensations and incentives, to be established in a specific law' may be used (Brazil 2009). It should be stressed that any attempt to tax emissions faces resistances, given the unpopularity of increasing the tax burden on citizens and companies (Pereira and Bertholini 2017). However, Brazil already has a legal framework developed regarding the use of economic instruments as mechanisms for environmental protection, in addition to having experienced destining part of taxes collected for social and environmental purposes - for example, the Ecological Tax on Circulation of Goods and Services (Ecological ICMS) and the Contribution of Intervention in the Economic Domain - Fuel (CIDE Fuels).

Nonetheless, in article 4, item VIII, it is affirmed that 'the development of the Brazilian Emission Reduction Market (MBRE) will be fostered' (Brazil 2009). Another reference to the use of an ETS occurs throughout the document, specifically in article 9, which states that this market 'will be operationalized in commodities and future exchanges, stock exchanges and organized over-the-counter entities authorized by the Securities and Exchange Commission (CVM), where it will be negotiated securities representing certified greenhouse gas emissions avoided.' In addition, Decree 7390/2010, which regulates some articles of the NPCC and imposes targets for GHG emissions from economic sectors, states in its article 4, item V, caption 3 that 'sectorial targets may be used as parameters for the establishment of the Brazilian Emission Reduction Market - MBRE.' No reference to possible fiscal or tax measures of carbon is presented in this Decree after all (Brazil 2010).

Since the promulgation of the NPCC in 2009, that was presented at COP 15 in Copenhagen, and the launch of its decree the in following year, reaching the Brazilian NDC in 2015, it can be seen that the carbon pricing agenda has always been present in political (and business) discussions. However, drawing from the analysis of the official documents essential to the design of the Brazilian climate policy, it is not clear how the national climate policy will be shaped in terms of which economic mechanisms and instruments for carbon pricing would help reach the goals taken on by the country. Nonetheless, the Brazilian Federal Government has shown an interest in analysing the CPI frameworks and assessing their potential impacts on the Brazilian economy (ICAP 2019; Brazil 2015a, 2015b).

In this context, the World Bank has established the Partnership for Market Readiness (PMR) through a trust fund supported by capacity-building grants. This partnership aims to provide 'implementing countries' with financial and technical support to build capacity 
to start structuring the main components of market readiness, such as data collection, monitoring, reporting and verification (MRV) system and/or construct pilot market instruments to define the correct scale of their mitigation efforts (Ministry of Finance [Brazil] 2014). The PMR also creates and shares a body of knowledge about market instruments, such as how to prepare market instruments and lessons learned.

In May 2012, the Partnership Assembly approved the allocation of funding for the preparation phase of Brazil based on what the country presented in its Organizing Framework for the Market Preparation Activities Scope (Ministry of Finance [Brazil] 2014). During the Brazilian market preparation proposal, the identified information gap began to be filled by studies commissioned by the Brazilian Ministry of Finance with the support of the PMR. In the context of implementing the Brazilian Market Readiness Proposal (MRP), the PMR Project is currently assisting the General Coordination of Environment and Climate Change of the Ministry of Finance's Secretariat of Economic Policy in the implementation of Component 1 and 2 of the Brazilian MRP. This includes conducting sectorial studies focusing on the electricity, fuel, industry and agriculture sectors/subsectors, as well as drawing up proposals for different CPI designs - the main instruments considered are ETS and/or carbon tax - aiming at helping assess the potential impacts of different design options.

The way each country designs and implements carbon pricing is influenced by its environmental, economic, social, political and institutional conditions. As a result, the incentive structures of a CPI vary widely, depending on each country's mitigation strategy. Therefore, the understanding of the institutional and regulatory framework is essential to the economic and distributive results from implementing a CPI (Santos 2018), reason why there are so many uncertainties about the future of this agenda in Brazil, given the political framework in the country in 2020 .

This becomes even more critical when we look at the recent global and regional advances in the carbon pricing agenda. Considering the regional perspective, Latin American countries are approaching CPIs through gradual efforts, mostly through the form of carbon taxes applied to fossil fuels. All existing CPIs can be expanded in scope, including more sources and fuels; tax rates could also be raised over time (World Bank et al 2019; ICAP 2019). On the other hand, transitioning to an ETS, as was recently the case in Mexico and under consideration in Argentina, Chile and Colombia, would allow for market linkages, with benefits such as increased funding for mitigation activities, to further help countries to reach their Paris Agreement goals. An ETS, also popularly known as a carbon market, is an instrument that aims to reduce GHG emissions cost-effectively by setting limits on emissions and enabling the trading of emission units, which are instruments that represent emission reductions.

International cooperation is a key issue when it comes to improving the cost-effectiveness of CPIs. As an example, globally integrated carbon markets could make it possible to achieve almost two times the emissions reductions from current climate policies with the same cost (Piris-Cabezas and Lubowski 2018). Regionally, the cooperation between smaller groups of countries can help to foster confidence among policymakers and 
businesses towards collaborative approaches to deal with climate change. In that sense, Mexico's intention to link up its prospective ETS with California and Quebec seems to represent a step in the right direction.

Another initiative worth mentioning is the Carbon Pricing in the Americas (CPA), a cooperative framework launched in December 2017 by the government leaders of Canada, Chile, Colombia, Costa Rica, México, the Governors of California and Washington in the United States, and the Premiers of Alberta, British Columbia, Nova Scotia, Ontario and Quebec in Canada. The initiative vows to strengthen Monitoring, Report and Verification (MRV) schemes, develop common standards, share best practices, build capacities and engage stakeholders, while asserting the CPIs' role as a central feature in climate policies.

Unfortunately, Brazil is not involved in any of these two projects, which shows that the country not only is losing its protagonist role in the region but is also losing a lot of opportunities to strengthen the efforts to achieve its NDC goals and its political, diplomatic and economic relations with its neighbours. Thus, Brazil's role in international cooperation in promoting regional carbon pricing can be compared to the queen in the chess. Although it is the most powerful (largest emitter in LA) and with greater possibility of moves, it can be (and has been) blocked by any piece (and by itself) in its path and has not been the most important actor in the game.

Metaphorically, despite the power to promote bold advances in the agenda, Brazil does not advance when other countries in the region (and Brazil itself) pose barriers, obstacles or threats. Therefore, in spite of its alleged interest, the country is unable to coordinate and lead the game between different pieces (States), being strongly dependent on the context and on the conjuncture - which is evident from the lack of participation in recent projects that are developed in the regional scope. In terms of the domestic perspective, there is also a strong lobby from the energy-intensive economic sectors that are afraid of losing their competitiveness both in terms of national and international commerce, rendering carbon pricing policies in Brazil difficult to be implemented (Santos 2018). These sectors cover relevant and strategic Brazilian economic groups such as industry, transportation and energy. These sectors are responsible for a large generation of employment and income, reason why any initiatives that may impact on the economic dynamics of these sectors encounter significant political resistance. Brazil plays like a daring queen who cannot skip any piece, highlighting conditions and constraints of its own (domestic) and of foreign (regional) nature (Kiessling 2018).

\section{Energy integration}

After analysing a case of Brazil's international cooperation with other Latin American countries in the climate chess, this subsection will specifically address energy integration with the other South American countries. 'It is important to note that although energy integration is considered a branch of physical integration, [we understand] that energy integration comprises a set of perspectives, being a physical and infrastructure theme, but also a political, institutional, economic, social and environmental one' (Santos 2018a: 35). 
Unlike the previous subsection, promoting Latin American energy integration is very complex, due to the geographic and physical peculiarity of incorporating Central America countries and the Caribbean islands and also because the region already has a very advanced initiative in this area - the Central American Electrical Interconnection System (SIEPAC). That way, we will focus on South America, analysing the regions of the Southern Common Market (Mercosur) and the Union of South American Nations (UNASUR).

The Mercosur was founded in 1991 with the Treaty of Asunción. Its main goal was to build up a common market between the four countries (Argentina, Brazil, Paraguay and Uruguay). Here, a historical analysis of the evolution of Mercosur will not be carried out; instead, we will focus on the energy sector, highlighting the role of (i) the Fund for the Structural Convergence of Mercosur (FOCEM); and (ii) the Working Subgroup (SGT-9). With regard to the issue of the different projects to be developed within Mercosur, the FOCEM is the first solidarity financing mechanism for the bloc countries that aims to reduce the existing asymmetries within them. Created at the end of 2004 and operating since 2006, the fund is based on a system of contributions and distribution of resources in an inverse manner, which means that countries with greater relative economic development make greater contributions, which, in turn, go to the countries that contribute the least.

The funds are intended for countries and delivered as a non-refundable donation to finance up to $85 \%$ of the eligible value of the projects presented. Contributions to FOCEM began in 2006, considering a total annual amount of US\$ $100 \mathrm{~m}$ up to 2012. Therefore, contributions are considered as a central point of any regional integration process aimed at reducing regional asymmetries.

Table 1 - Annual contributions and resources received in FOCEM (2015)

\begin{tabular}{lllll}
\hline Country & $\begin{array}{l}\text { Annual contributions } \\
\text { (US\$ millions) }\end{array}$ & $\%$ & $\begin{array}{l}\text { Annual resources received } \\
\text { (US\$ millions) }\end{array}$ & $\%$ \\
\hline $\mathrm{Br}$ & 70 & 55.12 & 11.55 & 9.09 \\
\hline $\mathrm{Ar}$ & 27 & 21.26 & 11.15 & 9.09 \\
\hline $\mathrm{Ve}$ & 27 & 21.26 & 11.50 & 9.06 \\
\hline Uy & 2 & 1.57 & 36.96 & 29.10 \\
\hline $\mathrm{Py}$ & 1 & 0.79 & 55.44 & 43.65 \\
\hline Total & 127 & 100.00 & 127.00 & 100.00 \\
\hline
\end{tabular}

Source: Created by the authors.

$\mathrm{Br}=\mathrm{Brazil} ; \mathrm{Ar}=$ Argentina; $\mathrm{Ve}=$ Venezuela; $U \mathrm{y}=$ Uruguay; $\mathrm{Py}=$ Paraguay; $\dagger$ in the period, Venezuela was still listed as a Mercosur state party.

Based on Table 1, Brazil is the country that contributes the most to FOCEM $(55,12 \%)$, while Paraguay has the least capital (0,79\%). This logic is related to the GDP size of each country. Conversely, the annual resources received go mainly to Paraguay $(44,65 \%)$ and 
Uruguay $(29,10 \%)$. In addition, taking into account the distribution of funds by programs, it is noteworthy that $43 \%$ goes to the infrastructure sector - including the energy one.

It is also interesting to note the existence of a Sub-Working Group within Mercosur that specializes in energy issues (SGT-9), created in 2005. Environmental issues are undertaken by SGT-6, acquiring a more political tone and dealing with some energy issues with climate impacts. Figure 1 therefore presents the evolution of SGT- 6 and SGT-9 meeting frequencies, 66 being SGT-6 (1996-2015) and only 16 SGT-9 (2005-2011). SGT-6 meetings have become even less frequent and there is no public information pre-2005 and post-2011 regarding SGT-9 meetings.

Figure 1 - The evolution of SGT-6 and SGT-9 meeting frequencies (1996-2015)

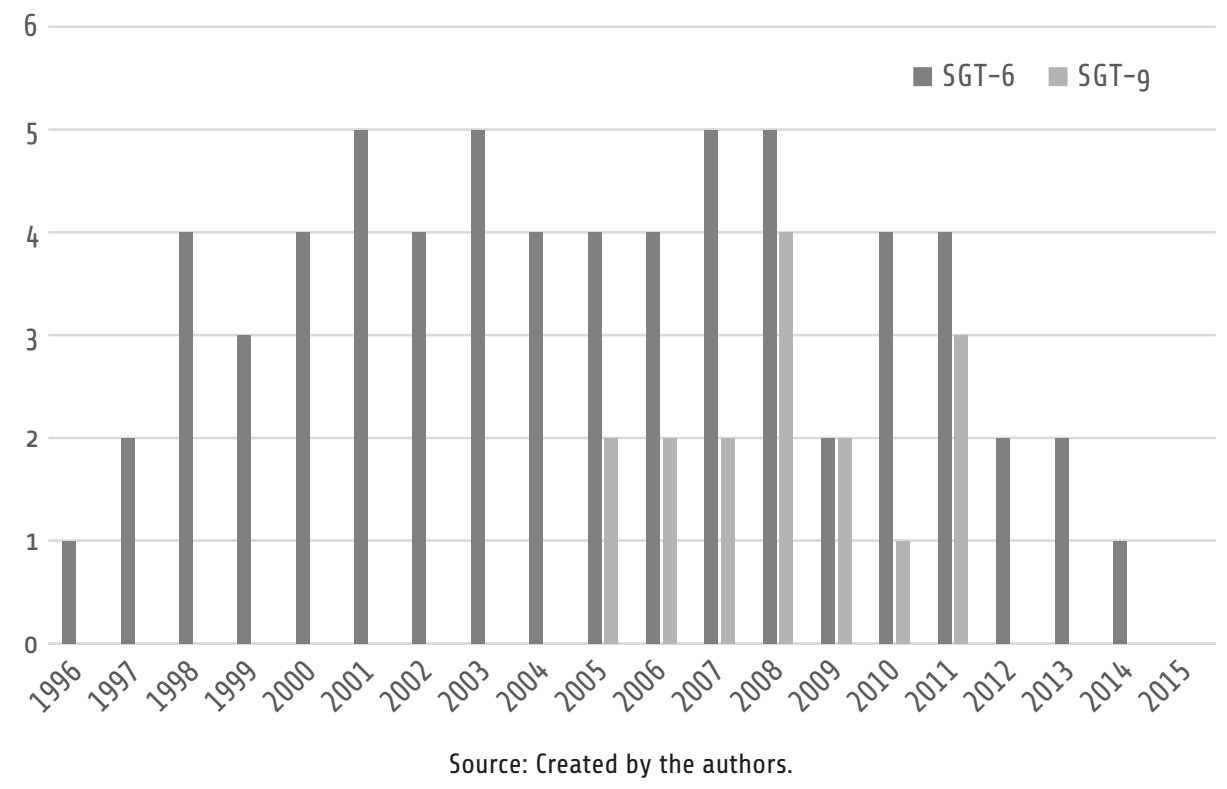

We can argue that SGT-9 did not act to structure and coordinate concrete policies or projects on regional energy integration. In the period comprehended by the Figure 1, it only worked on (i) the harmonization of energy regulation in order to facilitate exchanges; (ii) the elaboration of inventories on the electric sector; (iii) feeding databases to foster decisions in other instances; and (iv) the analysis of financial, legal and tax aspects of the sector. Although SGT-9 has daring objectives, these ended up not being reached by several reasons (Santos 2018a).

In this vein, SGT-9 lost some of its relevance and ceased meeting after the creation of the Union of South American Nations' (UNASUR) Energy Council, the corresponding technical forum, and following the negotiations of the UNASUR energy integration treaty. As already discussed, global environmental governance (GEG) is characterized by an overlap of initiative, and so is the nature of South American regional integration processes, characterized by the overlap of initiatives, which often deal with the same theme. In terms 
of energy, this occurs between the Mercosur, the Initiative for Regional Infrastructure Integration South America (IIRSA) and the UNASUR.

The IIRSA was created in 2000 and is the broadest one in the subcontinent and, consequently, UNASUR. This direct relationship between both institutions is given the fact that, since 2011, IIRSA was incorporated into the South American Council of Infrastructure and Planning (COSIPLAN), which is a forum for political and strategic discussion, efforts and articulation of programs and projects to foster regional infrastructure integration among UNASUR member countries. In turn, UNASUR was created in 2008.

Based on official data from UNASUR's COSIPLAN (2016), the investment portfolio estimated in 2016 was of US\$ $191420,10 \mathrm{~m}$ and had 581 projects. Considering this amount, $5(0.9 \%)$ were multinational, 94 (16.1\%) bi-national and $482(83 \%)$ national. Upon analysing the projects by type of financing, we noted that 475 (US\$ $117691 \mathrm{~m}$ ) were financed with pure public funding, 71 (US\$ $35926 \mathrm{~m}$ ) with pure private funding and 35 (US\$ 37803,1 m) with public-private or shared funding. There is a huge asymmetry in terms of project numbers and estimated investment value (US\$ $\mathrm{m}$ ) in the different Integration and Development Hubs (EIDs).

There is also a noteworthy asymmetry in the number of projects by countries. Argentina is the country with the most projects (178 projects, US $\$ 48565,9 \mathrm{~m}$ ), followed by Brazil (94, US\$ 82413,8 m), Chile (73, US\$ $16105 \mathrm{~m})$, and Peru (73, US\$11801,7 m). On the other hand, the countries with the fewest projects in terms of quantity and financial volume are Guyana (8, US\$ 911,9 m) and Suriname (7, US\$3831,9 m).

Among this project portfolio, 518 projects $(89,2 \%)$ come from the transport sector (US\$ $133958,90 \mathrm{~b}), 56$ projects $(9,6 \%)$ from the energy sector (US\$ $57419,70 \mathrm{~b}$ ), and 7 projects $(1,2 \%)$ from the communication sector (US\$ $41,50 \mathrm{~m})$. However, it is worth mentioning that the total amount of projects in the portfolio has evolved considerably over time. Between 2003 and 2004, for example, they were 335 projects (US\$ 37425,00 $\mathrm{m}$ ), while in 2010 there were 524 (US\$ 96119,20 m). As already presented, in 2016 they were 581 projects (US\$191420,10 m). During the whole period, projects summed up US\$ $1255,41 \mathrm{~b}$.

In terms of funding sources, there are pure public, pure private and public/private investment. In the energy sector, specifically, $53 \%$ of investments are public, $3 \%$ are private and $44 \%$ are public/private (COSIPLAN 2016). We noticed again that in terms of investments, the profile changes a lot for each sector, highlighting the share of public investments to guarantee investments in physical infrastructure in South America.

The periods in which Brazil was in the pro-tempore presidency of Mercosur (six months in 1992, 1994, 1996, 1998, 2000, 2002, 2004, 2006, 2008, 2010, 2012, 2014, 2017, and most recently, in 2019) did not correspond to those in that SGT-6 and SGT-9 were more active. In fact, in 2018 UNASUR started to dismantle with the unannounced suspension of the participation of six countries (Argentina, Brazil, Chile, Colombia, Paraguay and Peru). Brazil has formalized its decision to leave UNASUR shortly after being informed that Bolivia had handed over the pro-tempore presidency to Brazil in April 2019.

However, contrary to the assumption of reducing regional asymmetries, Brazil is one of the countries that most benefited from the projects related to COSIPLAN. Besides, 
contrary to energy integration, most of the energy projects deal only with national electricity generation, not facing harmonization of regulatory frameworks and/or bi-national or multilateral initiatives. Santos (2018a) shows how this asymmetry evolves over time, prioritizes national projects, focuses on the largest countries and on sectors that do not specifically cope with the challenges of South American regional integration.

Hence, Brazil's role in regional energy integration can be compared to the king piece in the climate chess. Considering energy integration as a way to diversify the regional energy matrix, to mitigate GHG emissions and to reduce the need for new ventures with negative socio-environmental and geographic impacts, the country's performance in the promotion of regional energy integration was not very bold. The reason therefor is the fact that, despite its regional importance in the theme (Santos 2018b), Brazil only moves one square in any given direction. Metaphorically, these shorter moves in (physical and regulatory) energy integration require more caution and care to progress. By drawing a parallel with the game of chess, the king can never move to a house at risk of attack.

Unlike some projects under the COSIPLAN umbrella, projects deal with harmonization of regulatory frameworks, joint regional planning, and collective optimization of energy systems. Precisely for these reasons, and because they involve international treaties, MOUs and contracts, they end up advancing in a slower, more resistant, and cautious way - especially in the face of increased regional uncertainty and the lack of a paymaster actor.

That way, it is again clear that Brazil's behaviour is not cohesive or unified, either depending on the level of analysis (national, regional or global), or depending on the regional initiative (cooperation or integration). Unlike what can be imagined and often suggested by specialized literature, different moves at different levels involve different actors, which is why the outcome of individual (national) and collective actions (regional and global) is significantly different. Thus, using chess metaphorically to analyse the role of a country by associating it with only one piece in the climate chess is inadequate, since one country actually represents many pieces whose moves (strategies) may also change depending on the circumstances and level of analysis.

\section{Conclusions}

There is no need for only top-down or only bottom-up initiatives, neither a country playing exactly the same role in different level of analysis. Multilevel governance suggests that are many possibilities rather than these traditional and rooted dichotomies to meet global environmental/climate challenges. Consequently, it is hard to argue for good or bad governance, since it actually relies on different actors, leadership capabilities, institutional arrangements, effective coordination, and political will.

The analysis proposed in this paper metaphorically compared the role of Brazil (chess piece) in climate governance (chessboard) at the national, regional and global levels. Although this type of analysis is very consolidated (and even common) in the IR literature, our proposal is innovative in a way that it in fact presents different roles for the same piece (State). Here, we realize that Brazil has played different roles, depending on the level 
of analysis and the subjects in question, evidencing a lack of solid strategy on this agenda. It is clear that the role played by Brazil is strongly influenced by the domestic situation, so its regional leadership ends up being fickle and even conflicting.

We concluded that at the national level, Brazil played as a pawn, since it presented continuous consistent moves, in a progressive way and gaining relevance as it progressed collectively. However, this behaviour has recently changed. Regionally, in both analysed cases - carbon pricing (queen moves) and energy integration (kind moves) - witnessed moves in all directions (including backwards/setbacks), showing that the regional and domestic context and situations decisively affect the Brazilian move, in line with the arguments by Franchini and Viola (2019) and Basso (2019).

Recently, though, and precisely after 2016, one can verify a change in the Brazilian behaviour regarding the climate agenda (and, more generally, in the environmental agenda). Even in the domestic case, whose role was associated with the pawn in the chessboard, Brazil acts as an unusual, atypical and wandering pawn. Breaking the rules of the (chess) game that has been consolidated for decades, the Brazilian pawn has been moving some back squares when, for instance, it (i) refused to host the last climate conference (COP 25) that happened on December 2019; and (ii) tried to reduce the protagonism of the Brazilian Ministry of the Environment (MMA) by joining it to the Ministry of Agriculture, Livestock and Food Supply (Mapa). Considering the climate agenda, it is possible to argue that Brazil has been recently presenting an increasingly moderate and conservative behaviour (Viola and Franchini 2018), making room for a series of questions from (inter)national civil and organized society. Recent cases like the oil spill in Brazil's northeast (September 2019), record deforestation in the Amazon Forest (April 2020), and wildfires in Brazil's Pantanal tropical wetland (September 2020) show the seriousness of the problem.

The same occurs regionally and globally, with Brazil (i) stifling the energy integration agenda (beyond regional integration itself, occurring in Mercosur and UNASUR as of 2020); (ii) presenting manifestations of interests to withdraw from the Paris Agreement; and (iii) relativizing and decreasing environmental/climate relevance on infrastructure projects guidelines. Thereafter, it is possible to argue that there is a strong uncertainty about the current environmental and climate agendas in Brazil, precisely after (i) the election of President Jair Bolsonaro; (ii) the conservative position and relativization of the theme by the current Minister of the MMA, Mr. Ricardo Salles; and (iii) the association of climate change with some kind of 'ideology' by the current Minister of Foreign Ministry (MRE), Mr. Ernesto Henrique Fraga Araújo.

Undoubtedly, this domestic situation has already been affecting the national position (domestic priorities) and regional (foreign policy) when it comes to climate governance. This poses doubts about the roles played by the country in the domestic, regional and global spheres. At the moment, the only certainty is that the initiatives carried out in the national and regional level can be associated with chess pieces, whose movements are uncertain, sometimes break the rules of the game, and are highly vulnerable to the national political-economic situation. 


\section{References}

Balsiger, J. 2011. 'New environmental regionalism and sustainable development.' Procedia Social and Behavioral Sciences (14): 44-48.

Balsiger, J and B Debarbieux. 2011. 'Major challenges in regional environmental governance research and practice.' Procedia Social and Behavioral Sciences (14): 1-8.

Balsiger, J and S D VanDeveer. 2010. 'Regional Governance and Environmental Problems.' In R A Denemark (ed), The International Studies Encyclopedia. Oxford: Wiley-Blackwell, pp. 6179-6200.

2012. 'Navigating regional environmental governance.' Global Environmental Politics 12 (3): 1-17.

Bárcena, A. 2015. Desafíos para una Gobernanza Ambiental Global y Regional. Santiago de Chile: ECLAC.

Basso, L. 'Brazilian energy-related climate (in)action and the challenge of deep decarbonization.' Revista Brasileira de Política Internacional 62 (2): 1-21.

Baud, M, F Castro and B Hogenboom. 2011. 'Environmental Governance in Latin America: Towards an Integrative Research Agenda.' European Review of Latin American and Caribbean Studies (90): 79-88.

Becker, B K. 2001. 'Amazonian Frontiers at the Beginning of the 21st Century'. In D J Hogan and M $\mathrm{T}$ Tolmasquim (eds), Human dimensions of global environmental change: Brazilian perspectives. Rio de Janeiro: Academia Brasileira de Ciências, pp. 299-324.

Bizzo, E and G Michener. 2017. 'Forest Governance without Transparency? Evaluating state efforts to reduce deforestation in the Brazilian Amazon.' Environmental Policy and Governance 27 (6): 560-574.

Brazil. 2009. Lei No. 12.187, de 29 dezembro de 2009 - Institui a Política Nacional sobre Mudança do Clima (PNMC) e dá outras providências. Brasília. 2010. Decreto $N^{\circ} 7.390$, de 9 de dezembro de 2010. Brasília.

2015a. Fundamentos para a elaboração da Pretendida Contribuição Nacionalmente Determinada (iNDC) do Brasil no contexto do Acordo de Paris sob a UNFCCC. Brasília.

. 2015b. Pretendida Contribuição Nacionalmente Determinada para Consecução do Objetivo da Convenção-Quadro das Nações Unidas sobre Mudança do Clima. Brasília.

Campello, L G B and V O Silveira. 2012. 'O princípio das responsabilidades comuns, porém diferenciadas no Direito Ambiental Internacional.' Revista Jurídica Consulex (374): 42-43.

Brazilian Business Council for Sustainable Development (CEBDS). 2016. Precificação de Carbono: O que o Setor Empresarial Precisa Saber para se Posicionar. Rio de Janeiro: CEBDS.

2017. Oportunidades e desafios da NDC brasileira para o setor empresarial brasileiro - Setor Industrial. Rio de Janeiro: CEBDS.

Cepei. 2018. Gobernanza Ambiental la Agenda 2030: Avances y buenas prácticas en América Latina y el Caribe. Ciudad de Panamá: Cepei.

Carbon Pricing Leadership Coalition (CPLC). 2017. Report of the high-level commission on carbon prices 2017: High-level Commission on carbon prices. Washington, DC: World Bank. 
Davenport, R B, J L Vivan, P H May, P C Nunes, L N de Vargas, W L S Costa, A R Oliveira and R L Rajão. 2017. 'Adaptive Forest Governance in Northwestern Mato Grosso, Brazil: Pilot project outcomes across agrarian reform landscapes.' Environmental Policy and Governance 27 (5): 453-471.

Debarbieux, B and G Rudaz. 2010. Les faiseurs de montagne. Paris: CNRS Editions.

De Castro, F, B Hogenboom and M Baud. 2016. Environmental Governance in Latin America. New York: Palgrave McMillan.

Dyer, H. 2010. 'International Relations Theory and the Environment.' In R A Denemark (ed), The International Studies Encyclopedia. Hoboken: Wiley.

Faria, C O and A Magrini. 2016. 'Biodiversity Governance from a Cross-Level and Cross-Scale Perspective: The case of the Atlantic Forest biome in Brazil.' Environmental Policy and Governance 26 (6): 468-481.

Gebara, M F, E Sills, P May and T Forsyth. 2019. 'Deconstructing the policyscape for reducing deforestation in the Eastern Amazon: Practical insights for a landscape approach.' Environmental Policy and Governance 29 (3): 185-197.

Greenpeace. 2019. 'Retrocessos ambientais marcam os 100 dias do governo Bolsonaro.' Greenpeace. At https://www.greenpeace.org/brasil/blog/retrocessos-ambientais-marcam-os-100-dias-do-governo-bolsonaro/ [Accessed on 8 February 2020].

Gurgel, A and S Paltsev. 2017. 'The Impacts of the Brazilian NDC and their contribution to the Paris Agreement on Climate Change.' Paper delivered at the 20th Annual Conference on Global Economic Analysis. West Lafayette: Center for Global Trade Analysis.

Hardin, G. 1968. 'Tragedy of the Commons.' Science (162): 1243-1248.

Held, D and C Roger. 2018. 'Three Models of Global Climate Governance: From Kyoto to Paris and Beyond.' Global Policy 9 (4): 527-537.

Hochstetler, K and C Y A Inoue. 2019. 'South-South relations and global environmental governance: Brazilian international development cooperation.' Revista Brasileira de Política Internacional 62 (2): 1-22.

Hochstetler, K. 2014. 'Latin America in Global Environmental Governance.' In J R Domínguez and A Covarrubias (ed), Routledge Handbook of Latin America in the World. New York and London: Routledge, pp. 391-403.

International Carbon Action Partnership (ICAP). 2019. Emissions Trading Worldwide: Status Report 2019. Berlin: ICAP. At https://icapcarbonaction.com/en/icap-status-report-2018 [Accessed on 10 February 2020].

National Institute for Space Research (INPE) [Brazil]. 2019. A estimativa da taxa de desmatamento por corte raso para a Amazônia Legal em 2019 é de 9.762 km². At http://www.inpe.br/noticias/noticia.php?Cod_Noticia=5294 [Accessed on 5 February 2020].

. 2020. DETER e DETER intenso. At http://www.obt.inpe.br/OBT/assuntos/programas/amazonia/deter [Accessed on 15 February 2020].

Intergovernmental Panel on Climate Change (IPCC). 2014. Climate Change 2014: Synthesis Report. Contribution of Working Groups I, II and III to the Fifth Assessment Report of the IPCC. Geneva, Switzerland.

Konrad Adenauer Stiftung and GVces. 2018. Policy BriefCarbon pricing instruments in Latin America. Latin America carbon pricing forum. At https:/www.kas.de/c/document_library/get_file?uuid=23a9288ad951-cb15-dd9f-e79464a474b0\&groupId=252038 [Accessed on 15 January 2020]. 
Keohane, R O and D G Victor. 2011. 'The regime complex for climate change.' Perspectives on Politics 9 (1): 7-23.

Kiessling, C K. 2018. 'Brazil, Foreign Policy and Climate Change (1992-2005).' Contexto Internacional 40 (2): $387-408$.

Kopper, A. 2017. 'What Image Does IR Project? Chess, a Visual Metaphor for IR.' International Studies Review 19 (3): 337-361.

Marks, M P. 2011. Metaphors in International Relations Theory. New York: Palgrave Macmillan.

Mauad, A and M Betsill. 2019. 'A changing role in global climate governance: São Paulo mixing its climate and international policies.' Revista Brasileira de Política Internacional 62 (2): 1-17.

Ministry of Finance [Brazil]. 2014. Market Readiness Proposal under the Partnership for Market Readiness Program.

Ministry of Science, Technology and Innovation [Brazil]. 2016. Cenários Integrados de Mitigação de Emissões de Gases de Efeito Estufa para o Brasil até 2050: Opções de Mitigação de Emissões de Gases de Efeito Estufa em Setores-Chave do Brasil. ONU Meio Ambiente: Brasília.

Morin, J F and A Orsini. 2013. 'Insights from Global Environmental Governance.' International Studies Review 15: 562-565.

Nye Jr, J S. 2002. The Paradox of American Power: Why the world's only superpower can't go it alone. New York: OUP. At https://www.foreignaffairs.com/reviews/capsule-review/2002-03-01/paradoxamerican-power-why-worlds-only-superpower-cant-go-it-alone [Accessed on 8 February 2020].

Ocampo, J A. 2015. Gobernanza global y desarrollo: Nuevos desafíos y prioridades de la cooperación internacional. $1^{\text {st }}$ ed. Buenos Aires: Siglo Veintiuno Editores.

O’Ryan, R and C Ibarra. 2017. 'Environmental Policy in Latin America.' In A Farazmand (ed), Global Encyclopedia of Public Administration, Public Policy, and Governance. Cham: Springer.

Paavola, J. 2016. 'Multi-Level Environmental Governance: Exploring the economic explanations.' Environmental Policy and Governance 26: 143-154.

Putnam, R D. 1988. 'Diplomacy and Domestic Politics: The Logic of Two-Level Games.' International Organization 42 (3): 427-460.

Saito-Jensen, M. 2015. Theories and Methods for the Study of Multi-Level Environmental Governance. Bogor: CIFOR. At https://www.jstor.org/stable/resrep02152 [Accessed on 28 January 2020].

Sandler, T. 1997. Global challenges: an approach to environmental, political, and economic problems. Cambridge: Cambridge University Press. At https://www.jstor.org/stable/24808901 [Accessed on 10 February 2020].

Santos, L. 2018. Proposal for the Implementation of a Carbon Pricing Instrument in the Brazilian Industry: assessing competitiveness risks and distributive impacts. Ph.D. Thesis, Federal University of Rio de Janeiro (UFRJ), Brazil. At http://www.ppe.ufrj.br/index.php/pt/publicacoes/teses-e-dissertacoes/2018/1416-proposal-for-the-implementation-of-a-carbon-pricing-instrument-in-the-brazilian-industry-assessing-competitiveness-risks-and-distributive-impacts [Accessed on 15 February 2020].

Santos, T. 2018a. Regional Energy Security: Re-evaluating concepts and policies to promote energy integration in Mercosur. Ph.D. Thesis, Federal University of Rio de Janeiro (UFRJ), Brazil. At http://www.ppe.ufrj. br/index.php/pt/publicacoes/teses-e-dissertacoes/2018/189-regional-energy-security-re-evaluating-concepts-and-policies-to-promote-energy-integration-in-mercosur [Accessed on 8 February 2020]. 
2018b. 'Furthering regional energy security instead of national approaches.' Revista de Economía del Caribe (22): 28-44.

Santos, L, R Garaffa and A F P Lucena. 2019. 'Would different methodologies for assessing carbon leakage exposure lead to different risk levels? A case study of the Brazilian industry. Climate Policy 19 (9): 1102-1116.

Santos, L, R Garaffa, A F P Lucena and A S Szklo. 2018. 'Impacts of Carbon Pricing on Brazilian Industry: Domestic Vulnerability and International Trade Exposure.' Sustainability 10: 2390-2409.

Saunier, R E and R A Meganck. 2009. Dictionary and Introduction to Global Environmental Governance. $2^{\text {nd }}$ ed. London: Earthscan.

Silva, L N. 2015. A proteção do meio ambiente sob a égide do princípio das responsabilidades comuns, porém diferenciadas. M.A. dissertation, Pontifical Catholic University of Goiás, Brazil.

South American Infrastructure and Planning Council (COSIPLAN). 2016. Cartera de Proyectos del COSIPLAN 2016. At http://www.iirsa.org/admin_iirsa_web/Uploads/Documents/Cartera\%20 2016_web.pdf [Accessed on 8 February 2020].

Stavins, R N. 2008. 'A Meaningful U.S. Cap-and-Trade System to Address Climate Change.' Harvard Environmental Law Review (32): 293-371.

VanDeveer, S D and H Selin. 2005. 'Canadian-U.S. Environmental Cooperation: Climate Change Networks and Regional Action.' American Review of Canadian Studies 35 (1): 353-378.

Viana, C, E Coudel, J Barlow, J Ferreira, T Gardner and L Parry. 2016. 'How Does Hybrid Governance Emerge? Role of the elite in building a Green Municipality in the Eastern Brazilian Amazon. Environmental Policy and Governance 26 (5): 337-350.

Vieira, M A. 2012. 'Brazilian Foreign Policy in the Context of Global Climate Norms.' Foreign Policy Analysis 9 (4): 369-386.

Viola, E and M Franchini. 2013. 'Brazil, Foreign Policy and Climate Change (1992-2005).' Contexto Internacional 35 (1): 43-76.

2018. Brazil and climate change beyond the Amazon. New York and London: Routledge.

2019. 'Myths and images in global climate governance, conceptualization and the case of Brazil (1989-2019).' Revista Brasileira de Política Internacional 62 (2): 1-21.

Winter, G. 2011. Multilevel governance of global environmental change: perspectives from science, sociology and the law. Cambridge: Cambridge University Press.

World Bank. 2011. Organização do Mercado Local de Carbono: Sistema Brasileiro de Controle de Carbono e Instrumentos Financeiros Relacionados. At http://www.pinheiropedro.com.br/biblioteca/ anais-e-relatorios/pdf/Estudo_BM\&F.pdf [Accessed on 1 February 2020].

2016. Emissions Trading in Practice: a handbook on design and implementation. NW: Washington, DC. At http://documents.worldbank.org/curated/en/353821475849138788/ Emissions-trading-in-practice-a-handbook-on-design-and-implementation [Accessed on 20 January 2020].

World Bank, Ecofys and Vivid Economics. 2019. State and Trends of Carbon Pricing 2019, Washington DC: WB. At http://documents.worldbank.org/curated/en/191801559846379845/pdf/ State-and-Trends-of-Carbon-Pricing-2019.pdf [Accessed on 8 February 2020]. 


\title{
About the authors
}

Thauan Santos is an Assistant Professor of the Graduate Programme in Maritime Studies at the Brazilian Naval War College (PPGEM/EGN). He holds a Ph.D. in Energy Planning from the PPE/COPPE/UFRJ, an M.A. in International Relations from IRI/PUC-Rio, and a BA in Economics from IE/UFRJ. His main research areas are sustainable development, energy, ocean governance, economy of the sea, and regional integration.

Luan Santos is an Assistant Professor of the Production Engineering Program from the Federal University of Rio de Janeiro (PEP/COPPE/UFRJ). He holds a Ph.D. and a MSc in Environmental and Energy Planning from the PPE/COPPE/UFRJ and a B.A. in Mathematics from IME/UFF and in Business Administration from the FACC/UFRJ. His main research areas are climate policy, green finance, carbon pricing, energy and environmental planning, and applied mathematics.

\section{Colocando em Xeque os Movimentos Brasileiros no Tabuleiro de Xadrez Climático}

\begin{abstract}
Resumo: Este artigo discute o papel do Brasil na governança climática, comparando-o metodológica e metaforicamente, às jogadas das peças de xadrez, com base em documentos nacionais e regionais oficiais, compromissos e dados. Ao contrário de outros estudos de RI, nossa proposta sugere diferentes comportamentos em diferentes níveis de análise para o mesmo país. Nacionalmente, o país desempenhou o papel de peão. Regionalmente, não há comportamento unitário: na cooperação internacional (no caso da precificação de carbono), ele se move como uma rainha; na integração regional (no caso da integração energética), como um rei. O cenário atual suscita dúvidas sobre esses papéis, sugerindo que o Brasil tem apresentado recentemente um comportamento cada vez mais moderado e conservador.
\end{abstract}

Palavras-Chave: Brasil; mudanças climáticas; agenda 2030; precificação de carbono; cooperação internacional; integração energética; governança climática.

Received on 28 February 2020, and approved for publication on 1 November 2020.

\section{(cc) BY-NC} https://creativecommons.org/licenses/by-nc/4.0/ 